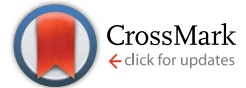

Cite this: Chem. Sci., 2015, 6, 917

Received 4th August 2014

Accepted 7th October 2014

DOI: $10.1039 / c 4 s c 02357 a$

www.rsc.org/chemicalscience

\title{
Tandem redox mediator/Ni(II) trihalide complex photocycle for hydrogen evolution from $\mathrm{HCl} \dagger$
}

\begin{abstract}
Seung Jun Hwang, ${ }^{a}$ David C. Powers, ${ }^{a}$ Andrew G. Maher ${ }^{\mathrm{ab}}$ and Daniel G. Nocera*a
Photoactivation of $\mathrm{M}-\mathrm{X}$ bonds is a challenge for photochemical HX splitting, particularly with first-row transition metal complexes because of short intrinsic excited state lifetimes. Herein, we report a tandem $\mathrm{H}_{2}$ photocycle based on combination of a non-basic photoredox phosphine mediator and nickel metal catalyst. Synthetic studies and time-resolved photochemical studies have revealed that phosphines serve as photochemical $\mathrm{H}$-atom donors to $\mathrm{Ni}\left({ }_{I}\right)$ trihalide complexes to deliver a $\mathrm{Ni}(\mathrm{I})$ centre. The $\mathrm{H}_{2}$ evolution catalytic cycle is closed by sequential disproportionation of $\mathrm{Ni}\left({ }_{1}\right)$ to afford $\mathrm{Ni}(\mathrm{O})$ and $\mathrm{Ni}(\mathrm{I})$ and protolytic $\mathrm{H}_{2}$ evolution from the $\mathrm{Ni}(\mathrm{O})$ intermediate. The results of these investigations suggest that $\mathrm{H}_{2}$ photogeneration proceeds by two sequential catalytic cycles: a photoredox cycle catalyzed by phosphines and an $\mathrm{H}_{2}$-evolution cycle catalyzed by $\mathrm{Ni}$ complexes to circumvent challenges of photochemistry with first-row transition metal complexes.
\end{abstract}

\section{Introduction}

The photochemical splitting of hydrohalic acids (HX) into $\mathrm{H}_{2}$ and $\mathrm{X}_{2}$ is an approach to solar fuel synthesis ${ }^{1}$ that stores a comparable amount of energy to water splitting. In addition to the similar energy densities implicit in $\mathrm{HX}$ and $\mathrm{H}_{2} \mathrm{O}$ splitting chemistries, HX splitting mandates management of only two electrons and two protons, whereas $\mathrm{H}_{2} \mathrm{O}$ splitting requires management of four protons and four electrons. ${ }^{2-5}$ Photocatalytic HX splitting requires accomplishing multielectron photochemical reactions to activate strong $\mathrm{M}-\mathrm{X}$ bonds. Typically, photoreduction has been the limiting step in HX splitting photocatalysis and often $\mathrm{X}_{2}$ elimination requires the use of chemical traps for evolved halogen equivalents. ${ }^{6-17}$ Attempts at promoting $\mathrm{HX}$ splitting with first-row transition metal complexes are attractive given that these metals are typically earth abundant, but have been largely unsuccessful. The challenge of using first-row metal complexes as HX splitting photocatalysts is that photochemical activation of $\mathrm{Ni}$ (I) or $\mathrm{Ni}$ (II) halides frequently does not lead to photoreduction reactions, ${ }^{18,19}$ likely due to the short excited state lifetimes of firstrow transition metal complexes. ${ }^{20-22}$

\footnotetext{
${ }^{a}$ Department of Chemistry and Chemical Biology, 12 Oxford Street, Cambridge, MA 02138-2902, USA.E-mail: dnocera@fas.harvard.edu

${ }^{b}$ Department of Chemistry, Massachusetts Institute of Technology, 77 Massachusetts Avenue, Cambridge, MA 02139-4307, USA

$\dagger$ Electronic supplementary information (ESI) available: Experimental procedures and time-dependent photochemical data; transient absorption spectroscopy and electrochemical experimental details. CCDC 992218-992221. For ESI and crystallographic data in CIF or other electronic format see DOI: 10.1039/c4sc02357a
}

To overcome the short excited state lifetimes typical of firstrow complexes, we have pursued a photoredox strategy for $\mathrm{H}_{2}$ evolution from $\mathrm{HCl}$ in which the photochemistry and $\mathrm{H}_{2}$ evolution roles are separated between a photoredox mediator and a hydrogen-evolution catalyst, respectively. ${ }^{23}$ We were attracted to this strategy because it does not rely on molecular excited states of first-row metal complexes. In our first foray into photoredox catalysis for $\mathrm{H}_{2}$ evolution, we employed bipyridines as photoredox mediators and Ni polypyridyl complexes as $\mathrm{H}_{2}$ evolution catalysts. H-atom abstraction (HAA) by the excited state of the bipyridine afforded a pyridinyl radical, which engaged with a $\mathrm{Ni}$ (II) halide complex to generate a $\mathrm{Ni}(\mathrm{I})$ intermediate via halogen radical abstraction. The resulting $\mathrm{Ni}(\mathrm{I})$ complex underwent disproportionation to a Ni(II) complex and a $\mathrm{Ni}(0)$ species, which subsequently engaged in protolytic $\mathrm{H}_{2}$ evolution. While these efforts demonstrated a synthetic cycle for $\mathrm{H}_{2}$ evolution, $\mathrm{H}_{2}$-evolution catalysis was not observed because the basic bipyridyl photoredox mediator was passivated in the presence of $\mathrm{HCl}$.

To address the challenges of photoredox catalysis for $\mathrm{H}_{2}$ evolution from $\mathrm{HCl}$, we turned our attention to identifying a photoredox mediator that could function under acidic conditions. We now examine the role of phosphines as photoredox mediators under acidic conditions $\left(\mathrm{p} K_{\mathrm{a}}\right.$ in $\mathrm{CH}_{3} \mathrm{CN}: \mathrm{PPh}_{3}=7.64$; pyridine $=12.53) .{ }^{24}$ The photochemical homolysis of $\mathrm{P}-\mathrm{H}$ bonds of $2^{\circ}$ phosphines generates phosphinyl radicals that display sufficient lifetime $(\sim 160 \mu \mathrm{s})$ to participate in halogen-atom abstraction from a $\mathrm{Ni}$ (II) halide complex to furnish a reduced $\mathrm{Ni}$ intermediate that participates in an $\mathrm{H}_{2}$ evolution cycle; the phosphine photoredox mediator is regenerated by HAA from solvent to close the photocycle. ${ }^{25-27}$ The $\mathrm{H}_{2}$-evolution cycle may 
eventually be closed by thermally promoted protolytic $\mathrm{H}_{2}$ evolution with $\mathrm{HCl}$.

\section{Experimental}

\section{Materials and methods}

All reactions were carried out in an $\mathrm{N}_{2}$-filled glovebox. Anhydrous solvents were obtained by filtration through drying columns. ${ }^{28}$ NMR chemical shifts are reported in ppm with the residual solvent resonance as internal standard. UV-vis spectra were recorded at $293 \mathrm{~K}$ in quartz cuvettes on a Spectral Instruments 400 series diode array and were blanked against the appropriate solvent. $\mathrm{PhICl}_{2}{ }^{29}$ and $\mathrm{Ni}\left(\mathrm{PPh}_{3}\right)_{2}\left(\mathrm{CH}_{2}=\mathrm{CH}_{2}\right)^{30}$ were prepared according to reported procedures. $\mathrm{NiCl}_{2} \mathrm{dme}(\mathrm{dme}=$ 1,2-dimethoxyethane) and AgOTf (OTf $=$ trifluoromethanesulfonate) were obtained from Strem Chemicals. $\mathrm{Cl}_{2} \mathrm{PPh}_{3}$, prepared by treatment of $\mathrm{PPh}_{3}$ with $\mathrm{PhICl}_{2}$, displayed spectral features identical to those reported in the literature. ${ }^{31}$ $\mathrm{NiCl}_{2}\left(\mathrm{PPh}_{3}\right)_{2}$ (1), $\mathrm{Ni}\left(\mathrm{PPh}_{3}\right)_{4}(5)$, tetrabutylammonium chloride $\left({ }^{n} \mathrm{Bu}_{4} \mathrm{NCl}\right)$, tetraethylammonium chloride $\left({ }^{n} \mathrm{Et}_{4} \mathrm{NCl}\right)$, and triphenylphosphine $\left(\mathrm{PPh}_{3}\right)$ were obtained from Sigma Aldrich. All chemicals were used without further purification. Elemental analysis was obtained by Complete Analysis Laboratories, Inc., New Jersey. Evolved hydrogen was quantified by gas chromatography using a calibration curve derived from adding $\mathrm{HCl}$ to known quantities of $\mathrm{NaH}$; over the relevant concentration range, the gas chromatograph response was linear. This procedure has previously been validated by comparison with Toepler pump combustion analysis. ${ }^{15}$

\section{Preparation of $\mathrm{Ni}(\mathrm{II})$ trihalide complexes}

Complex 2[ClPPh $]$. A solution of $\mathrm{PhICl}_{2}\left(9.1 \mathrm{mg}, 3.30 \times 10^{-5}\right.$ mol, 1.00 equiv.) in $1 \mathrm{~mL}$ of $\mathrm{CH}_{2} \mathrm{Cl}_{2}$ was added to a solution of $\mathrm{NiCl}_{2}\left(\mathrm{PPh}_{3}\right)_{2}\left(21.4 \mathrm{mg}, 3.30 \times 10^{-5} \mathrm{~mol}, 1.00\right.$ equiv. $)$ in $2 \mathrm{~mL}$ of $\mathrm{CH}_{2} \mathrm{Cl}_{2}$ to prompt an immediate colour change from a light beige to blue. The solvent was removed in vacuo, and the resulting solid was treated with pentane. The pentane was decanted, and the resulting solid was dried in vacuo to afford $21.5 \mathrm{mg}$ of title compound (90\% yield). ${ }^{1} \mathrm{H}$ NMR $(600 \mathrm{MHz}$, $\left.\mathrm{CD}_{3} \mathrm{CN}\right) \delta(\mathrm{ppm}): 7.77(\mathrm{~m}, 9 \mathrm{H}), 7.64(\mathrm{~m}, 6 \mathrm{H}) \cdot \mu_{\mathrm{eff}}\left(\mathrm{CH}_{3} \mathrm{CN}\right)=4.20$ $\mu_{\mathrm{B}}$. Anal. calcd (found) for $\mathrm{C}_{36} \mathrm{H}_{30} \mathrm{Cl}_{4} \mathrm{NiP}_{2}$ : C, 59.63 (59.53); $\mathrm{H}$, 4.17 (4.09). Crystals suitable for single-crystal diffraction analysis were obtained from a $\mathrm{CH}_{3} \mathrm{CN}$ solution of the complex layered with $\mathrm{Et}_{2} \mathrm{O}$.

Complex 2[TBA]. To a suspension of $\mathrm{NiCl}_{2}(\mathrm{dme})(40.0 \mathrm{mg}$, $1.82 \times 10^{-4}$ mol, 1.00 equiv.) in $\mathrm{CH}_{2} \mathrm{Cl}_{2}$ was added $\mathrm{PPh}_{3}(47.7$ $\mathrm{mg}, 1.82 \times 10^{-4} \mathrm{~mol}, 1.00$ equiv.) and ${ }^{n} \mathrm{Bu}_{4} \mathrm{NCl}$ (50.6 mg, 1.82 $\times 10^{-4} \mathrm{~mol}, 1.00$ equiv.) as a solid. The reaction solution immediately turned from yellow to blue. The reaction mixture was stirred at $23{ }^{\circ} \mathrm{C}$ for $1 \mathrm{~h}$. The reaction was concentrated to dryness and the residue was taken up in pentane and $\mathrm{Et}_{2} \mathrm{O}$, solvent was decanted, and the residue was dried in vacuo to afford $119 \mathrm{mg}$ of the title complex as a blue solid (98\% yield). ${ }^{1} \mathrm{H}$ NMR (600 MHz, CD $\left.3 \mathrm{CN}\right) \delta(\mathrm{ppm}): 3.32(\mathrm{q}, 2 \mathrm{H}), 1.83(\mathrm{~m}, 2 \mathrm{H})$, $1.53(\mathrm{~m}, 2 \mathrm{H}), 1.08(\mathrm{t}, 3 \mathrm{H}) . \mu_{\text {eff }}\left(\mathrm{CH}_{3} \mathrm{CN}\right)=4.02 \mu_{\mathrm{B}}$. Anal. calcd (found) for $\mathrm{C}_{34} \mathrm{H}_{51} \mathrm{Cl}_{3} \mathrm{NNiP}$ : C, 60.97 (60.93); $\mathrm{H}, 7.68$ (7.58); N,
2.09 (2.06). Complex 2[TEA] was prepared analogously by substitution of ${ }^{n} \mathrm{Bu}_{4} \mathrm{NCl}$ with ${ }^{n} \mathrm{Et}_{4} \mathrm{NCl}$ in $95 \%$ yield; ${ }^{1} \mathrm{H}$ NMR $\left(600 \mathrm{MHz}, \mathrm{CD}_{3} \mathrm{CN}\right) \delta(\mathrm{ppm}): 3.48(\mathrm{q}, 2 \mathrm{H}), 1.45(\mathrm{t}, 3 \mathrm{H}) \cdot \mu_{\text {eff }}$ $\left(\mathrm{CH}_{3} \mathrm{CN}\right)=4.17 \mu_{\mathrm{B}}$. Anal. calcd (found) for $\mathrm{C}_{26} \mathrm{H}_{35} \mathrm{Cl}_{3} \mathrm{NNiP}: \mathrm{C}$, 56.01 (56.14); H, 6.33 (6.26); N, 2.51 (2.67). Crystals suitable for single-crystal diffraction analysis were obtained from a $\mathrm{CH}_{3} \mathrm{CN}$ solution of the complex layered with $\mathrm{Et}_{2} \mathrm{O}$ and unit cell data matched literature reports. ${ }^{32}$

\section{Preparation of $\left[\mathrm{ClPPh}_{3}\right]$ OTf}

To a solution of $\mathrm{Cl}_{2} \mathrm{PPh}_{3}\left(127 \mathrm{mg}, 3.81 \times 10^{-4} \mathrm{~mol}, 1.00\right.$ equiv.) in $\mathrm{CH}_{2} \mathrm{Cl}_{2}$ was added AgOTf $\left(98.0 \mathrm{mg}, 3.81 \times 10^{-4} \mathrm{~mol}, 1.00\right.$ equiv.) as a suspension in $\mathrm{CH}_{2} \mathrm{Cl}_{2}$. White solid immediately precipitated when AgOTf was added and the reaction mixture was stirred at $23^{\circ} \mathrm{C}$ for $1 \mathrm{~h}$ before being filtered through Celite. The filtrate was concentrated in vacuo and the residue was taken up in THF and solvent was decanted, and the residue was dried in vacuo to afford $157 \mathrm{mg}$ of the title compound as a white solid (92\% yield). ${ }^{31} \mathrm{P}$ NMR (160 MHz, $\mathrm{CD}_{2} \mathrm{Cl}_{2}$ ) $\delta$ (ppm): 66.4; ${ }^{19} \mathrm{~F}$ NMR $\left(275 \mathrm{MHz}, \mathrm{CD}_{2} \mathrm{Cl}_{2}\right) \delta(\mathrm{ppm}):-78.9$. The spectral data is consistent with that reported for $\mathrm{ClPPh}_{3} \cdot \mathrm{AlCl}_{4} \cdot{ }^{33}$ Crystals suitable for single-crystal diffraction analysis were obtained from a $\mathrm{CH}_{2} \mathrm{Cl}_{2}$ solution layered with $\mathrm{Et}_{2} \mathrm{O}$.

\section{Preparation of Ni(II) tetrachloride complex $\left[\mathrm{NiCl}_{4}\right]\left[\mathrm{Et}_{4} \mathrm{~N}\right]_{2}$}

A solution of ${ }^{n} \mathrm{Et}_{4} \mathrm{Cl}$ (30.2 mg, $1.82 \times 10^{-4} \mathrm{~mol}, 1.00$ equiv.) in 2 $\mathrm{mL}$ of $\mathrm{CH}_{2} \mathrm{Cl}_{2}$ was added to a solution of $\mathrm{NiCl}_{2}$ (dme) (40.0 mg, $1.82 \times 10^{-4}$ mol, 1.00 equiv.) in $2 \mathrm{~mL}$ of $\mathrm{CH}_{2} \mathrm{Cl}_{2}$ to prompt an immediate colour change from yellow to green. After stirring at $23{ }^{\circ} \mathrm{C}$ for $0.5 \mathrm{~h}$, the reaction mixture was concentrated to dryness and the residue was taken up in pentane and solvent was decanted, and the residue was dried in vacuo to afford 77.2 $\mathrm{mg}$ of the title compound as a green solid ( $92 \%$ yield). Crystals suitable for single-crystal diffraction analysis were obtained from a $\mathrm{CH}_{3} \mathrm{CN}$ solution layered with $\mathrm{Et}_{2} \mathrm{O}$ and unit cell data matched literature reports. ${ }^{34}$

\section{Preparation of Ni(I) complexes}

Complex 3. To a scintillation vial was added $\mathrm{Ni}(\operatorname{cod})_{2}$ (58.0 mg, $2.10 \times 10^{-4} \mathrm{~mol}, 1.00$ equiv.) and $\mathrm{NiCl}_{2}(\mathrm{dme})(46.0$ $\mathrm{mg}, 2.10 \times 10^{-4} \mathrm{~mol}, 1.00$ equiv.) as solids, followed by $3 \mathrm{~mL}$ of $\mathrm{PhCH}_{3}$. To this solution was added $\mathrm{PPh}_{3}\left(330 \mathrm{mg}, 1.26 \times 10^{-3}\right.$ mol, 6.00 equiv.) dissolved in $2 \mathrm{~mL} \mathrm{PhCH}_{3}$ and the reaction mixture was stirred at $23{ }^{\circ} \mathrm{C}$ for $12 \mathrm{~h}$ before being filtered through Celite. The filtrate was concentrated in vacuo to a volume of $1.5 \mathrm{~mL}$, layered with hexanes, and cooled to $-30{ }^{\circ} \mathrm{C}$ to afford yellow crystalline solid (80\% yield). ${ }^{1} \mathrm{H}$ NMR (600 MHz, THF- $\left.d_{8}\right) \delta$ (ppm): 9.51 (br, s, 20H), 5.28 (br, s, 15H), 4.20 (br, s, $10 \mathrm{H}) . \mu_{\text {eff }}\left(\mathrm{CH}_{3} \mathrm{CN}\right)=1.74 \mu_{\mathrm{B}}$. Crystals suitable for singlecrystal diffraction analysis were obtained from a $\mathrm{PhCH}_{3}$ solution of the complex layered with $n$-hexane and collected unit cell data matched literature reports. ${ }^{35}$

Complex 4. To a scintillation vial was added $\mathrm{Ni}\left(\mathrm{PPh}_{3}\right)_{2}$ $\left(\mathrm{CH}_{2}=\mathrm{CH}_{2}\right)\left(20.0 \mathrm{mg}, 3.30 \times 10^{-5} \mathrm{~mol}, 1.00\right.$ equiv. $)$ and $\mathrm{NiCl}_{2}\left(\mathrm{PPh}_{3}\right)_{2}\left(21.4 \mathrm{mg}, 3.30 \times 10^{-5} \mathrm{~mol}, 1.00\right.$ equiv. $)$ as solids followed by $4 \mathrm{~mL}$ of $\mathrm{Et}_{2} \mathrm{O}$. The reaction mixture was stirred at 
$23{ }^{\circ} \mathrm{C}$ for $0.5 \mathrm{~h}$, during which time a yellow precipitate was observed. The mixture was concentrated to dryness and the residue was taken up in pentane and dried in vacuo to afford $18.4 \mathrm{mg}$ of the title complex as a yellow solid ( $90 \%$ yield). ${ }^{36}$

\section{Results and discussion}

We targeted phosphines as potential photoredox mediators for a tandem photoredox/transition metal catalysed $\mathrm{H}_{2}$-evolution photocycle from $\mathrm{HCl}$ based on their demonstrated ability to serve as photochemical $\mathrm{H}$-atom donors. ${ }^{27}$ To evaluate the viability of the proposed phosphine-mediated photoredox approach for $\mathrm{H}_{2}$ evolution, we photolyzed $\mathrm{Ni}(\mathrm{II})$ complex $\mathrm{NiCl}_{2}\left(\mathrm{PPh}_{3}\right)_{2}(\mathbf{1})$ in THF $(\lambda>295 \mathrm{~nm})$ in the presence of 1.0 equiv. $\mathrm{PPh}_{3}$ and 15 equiv. of $\mathrm{HCl}$. The light beige reaction solution turned pale blue upon photolysis. Analysis of the headspace by gas chromatography (GC) confirmed $\mathrm{H}_{2}$ as the exclusive gaseous product under these conditions; integration of the chromatogram and comparison to a $\mathrm{H}_{2}$ calibration curve generated from the reaction of $\mathrm{NaH}$ with $\mathrm{HCl}$ revealed that 3.1 turnovers had been achieved in $18 \mathrm{~h}$. $\mathrm{NiCl}_{2}\left(\mathrm{PPh}_{3}\right)_{2}$ participates in ligand dissociation equilibria to release $\mathrm{PPh}_{3}$ (vide infra), ${ }^{37}$ and thus $\mathrm{H}_{2}$-evolving photocatalysis was also observed in the absence of exogenous $\mathrm{PPh}_{3}$. Evaluation of the amount of $\mathrm{H}_{2}$ evolved as a function of time (Fig. 1), showed that in the

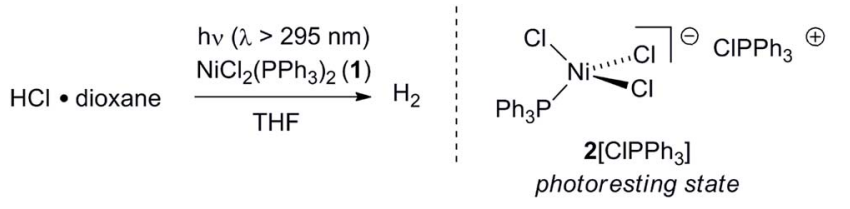

(a)

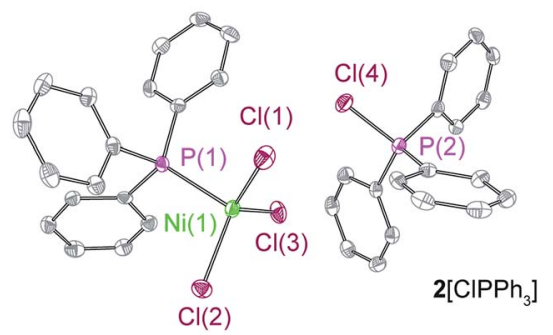

(b)

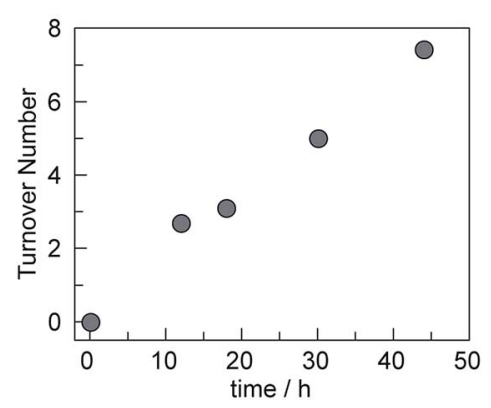

Fig. 1 Photolysis of $\mathrm{NiCl}_{2}\left(\mathrm{PPh}_{3}\right)_{2}$ in THF $(\lambda>295 \mathrm{~nm})$ in the presence of 15 equiv. of $\mathrm{HCl}$ affords $\mathrm{H}_{2}$ as well as 2[CIPPh 3 . (a) Thermal ellipsoid plot of $2\left[\mathrm{ClPPh}_{3}\right]$ drawn at the $50 \%$ probability level. The hydrogen atoms are omitted for clarity. (b) Time-dependent turnover number (TON) of $\mathrm{H}_{2}$ produced by a $4.5 \mathrm{mM}$ THF solution of $\mathrm{NiCl}_{2}\left(\mathrm{PPh}_{3}\right)_{2}$ in the presence of 15 equiv. $\mathrm{HCl}(\lambda>295 \mathrm{~nm})$. presence of excess $\mathrm{HCl}, \mathrm{H}_{2}$ evolution continues and 9 turnovers were achieved after $44 \mathrm{~h}$ with no signs of deactivation.

During the photolysis of $\mathrm{NiCl}_{2}\left(\mathrm{PPh}_{3}\right)_{2}$, the blue-coloured solution that initially develops persists throughout subsequent $\mathrm{H}_{2}$ evolution and based on UV-vis measurements, appears to represent the photoresting state of the catalyst system. The pale blue photoproduct was identified as Ni(II) trihalide complex $2\left[\mathrm{ClPPh}_{3}\right]$ by single-crystal X-ray diffraction analysis.t In addition, comparison of the in situ UV-vis spectrum obtained during $\mathrm{H}_{2}$-evolving catalysis with a spectrum obtained from an authentic sample of $2\left[\mathrm{ClPPh}_{3}\right]$, prepared by treatment of $\mathrm{NiCl}_{2}\left(\mathrm{PPh}_{3}\right)_{2}$ with 1.0 equiv. of $\mathrm{PhICl}_{2}$ (Fig. $\mathrm{S} 15 \dagger$ ), confirmed the identity of the catalyst resting state. Independently isolated complex $2\left[\mathrm{ClPPh}_{3}\right]$ is chemically competent at $\mathrm{H}_{2}$ generation under above photoreaction conditions.

Catalyst resting state $2\left[\mathrm{ClPPh}_{3}\right]$ is constituted of a Ni trichloride anion and a phosphonium cation. In order to establish the roles of both the Ni complex and phosphine in the observed $\mathrm{H}_{2}$ evolution reaction, 2[TBA] and phosphonium cation [ClPPh 3 OTf were independently prepared. As summarized in Table 1, $\mathrm{Ni}$ (II) complex 2[TBA] showed a similar activity toward $\mathrm{HCl}$ with $5.0 \mathrm{TON}$ in $18 \mathrm{~h}$. Complex 2[TBA] also participates in a minor equilibrium with free $\mathrm{PPh}_{3}$ (vide infra) and thus both catalyst and photoredox mediator are present when $2[\mathrm{TBA}]$ is employed as the photocatalyst. In contrast, phosphonium salt $\left[\mathrm{ClPPh}_{3}\right] \mathrm{OTf}$ does not produce $\mathrm{H}_{2}$ under the same reaction conditions. Additionally, neither $\mathrm{PPh}_{3}$ or $\left[\mathrm{NiCl}_{4}\right][\mathrm{TEA}]_{2}$ is a competent $\mathrm{H}_{2}$-evolution catalyst, confirming the necessity of both Ni complex and phosphine for productive $\mathrm{H}_{2}$ evolution chemistry.

Fig. 2 illustrates a tandem catalytic cycle that accounts for the photogeneration of $\mathrm{H}_{2}$ from $\mathrm{HCl}$ catalyzed by the Ni phosphine complexes and phosphine photoredox mediators. Diphenyl phosphine is initially formed by photochemical cleavage of the $\mathrm{P}-\mathrm{C}$ bond and $\mathrm{H}$-atom abstraction from solvent. ${ }^{27}$ Photochemical cleavage of the $\mathrm{P}-\mathrm{H}$ bond in $\mathrm{HPPh}_{2}$ generates an $\mathrm{H}$-atom equivalent and a diphenylphosphinyl radical. ${ }^{27}$ The $\mathrm{H}$-atom participates in halogen-atom abstraction with $\mathrm{Ni}(\mathrm{II})$ resting state 2 to generate a $\mathrm{Ni}(\mathrm{I})$ intermediate while the accompanying diphenylphosphinyl radical participates in $\mathrm{C}-\mathrm{H}$ abstraction with solvent to regenerate the diphenylphosphine and close the photoredox cycle. Ni(I) intermediate 3 undergoes disproportionation to afford $\mathrm{NiCl}_{2}\left(\mathrm{PPh}_{3}\right)_{2}(\mathbf{1})$ and $\mathrm{Ni}\left(\mathrm{PPh}_{3}\right)_{4}$ (5). Protonolysis of $\mathrm{Ni}(0)$ complex 5 affords $\mathrm{H}_{2}$ and regenerates $\mathrm{Ni}$ (II) dihalide $\mathbf{1}$, thus closing the hydrogen

Table 1 TON of $\mathrm{H}_{2}$ measured in the headspace upon photolysis of designated compounds in the presence of 15 equiv. $\mathrm{HCl}$ in THF for $18 \mathrm{~h}$

\begin{tabular}{ll}
\hline & $\mathrm{HCl} \stackrel{h v(\lambda>295 \mathrm{~nm}) \text { compound }}{\stackrel{\mathrm{THF}, 18 \mathrm{~h}}{\longrightarrow} \mathrm{H}_{2}}$ \\
\hline Compound & $\mathrm{TON}$ \\
\hline $2\left[\mathrm{ClPPh}_{3}\right]$ & 2.0 \\
$\mathrm{PPh}_{3}$ & 0 \\
{$\left[\mathrm{NiCl}_{4}\right]\left[\mathrm{Et}_{4} \mathrm{~N}\right]_{2}$} & 0 \\
$2[\mathrm{TBA}]$ & 5.0 \\
{$\left[\mathrm{ClPPh}_{3}\right] \mathrm{OTf}$} & 0
\end{tabular}




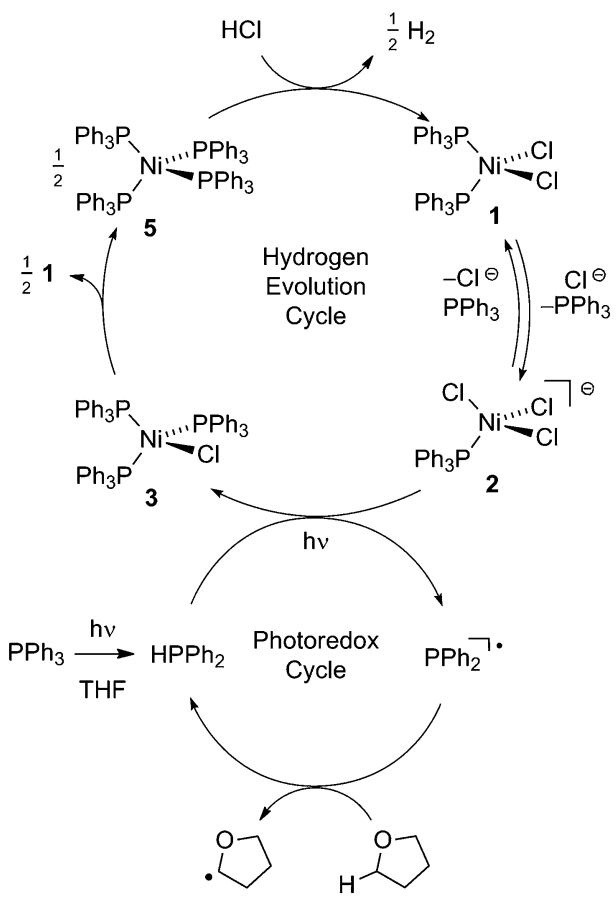

Fig. 2 Proposed tandem catalytic cycles for $\mathrm{H}_{2}$-generation with $\mathrm{Ni}$ based $\mathrm{H}_{2}$-evolution catalysts and phosphine-based photoredox mediators.

evolution cycle. The number of phosphine ligands bound to intermediates in the tandem cycle illustrated in Fig. 2 is unknown. Isolated complexes $2\left[\mathrm{ClPPh}_{3}\right], \mathbf{3}, \mathbf{4}$ and $\mathbf{5}$, which display 1-4 phosphine ligands per $\mathrm{Ni}$, are all competent catalysts for $\mathrm{H}_{2}$ evolution and proceed with the same photoresting state $\left(2\left[\mathrm{ClPPh}_{3}\right]\right)$, demonstrating ligand dissociation equilibria ${ }^{37}$ are established during catalysis (Fig. S16 $\dagger$ ).

In order to probe the contention that photogenerated diphenylphosphinyl radicals could mediate the reduction of a $\mathrm{Ni}-\mathrm{Cl}$ bond from the $\mathrm{Ni}(\mathrm{II})$ trihalide complex, we carried out time-resolved photochemical experiments. On the picosecond timescale, a transient absorption (TA) difference spectrum obtained by laser flash photolysis $\left(\lambda_{\mathrm{exc}}=310 \mathrm{~nm}\right.$, THF solutions) of 2[TBA] exhibits a spectral growth centred at $506 \mathrm{~nm}$ with a lifetime of $\sim 700$ ps (Fig. S18 $\dagger$ ). An identical spectral feature was observed during laser flash photolysis of $\mathrm{PPh}_{3}$ solutions. This feature was assigned to be that of the singlet excited state of $\mathrm{PPh}_{3}$, and the observation of this signal in the TA spectrum of $2[\mathrm{TBA}]$ supports the presence of a minor equilibrium between $2[\mathrm{TBA}]$ and free $\mathrm{PPh}_{3} \cdot{ }^{38}$ Additional support for this ligand dissociation equilibrium is the observation that both 2 [TBA] and $\mathrm{PPh}_{3}$ both show an emission band centred at 500 nm with a 900 ps lifetime (Fig. S17 $\dagger$ ), which is well-matched to reported $\mathrm{PPh}_{3}$ photophysics. ${ }^{39}$ The similar emission lifetimes for both $2[\mathrm{TBA}]$ and $\mathrm{PPh}_{3}$ excludes dynamic quenching of the excited ${ }^{1} \mathrm{PPh}_{3}{ }^{*}$ species by the Ni complex and suggests that the relatively low steady-state emission intensity observed for 2 [TBA] is due only to a low equilibrium concentration of $\mathrm{PPh}_{3}$.

The photochemistry of 2 and $\mathrm{PPh}_{3}$ were also examined at longer time scales by nanosecond flash photolysis (Fig. 3). Flash

$$
\mathrm{PPh}_{3} \underset{\tau=160 \mu \mathrm{s}}{\stackrel{\mathrm{hv}(\lambda>295 \mathrm{~nm})}{\longrightarrow}} \cdot \mathrm{PPh}_{2}+\bullet \mathrm{Ph}
$$

(a)

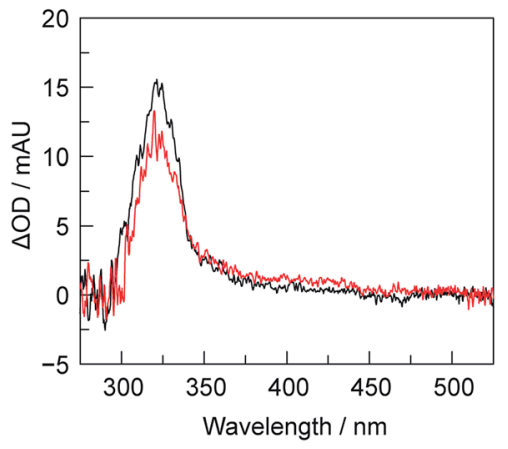

(b)

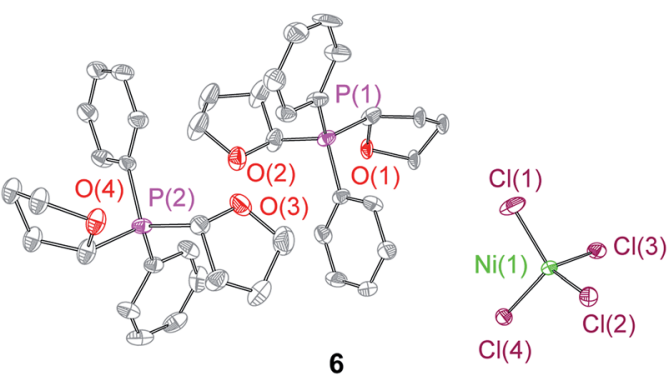

Fig. 3 (a) Nanosecond transient absorption (TA) spectroscopy of $\mathrm{Ni}$ complex 2[TEA] (-, red) and $\mathrm{PPh}_{3}(-$, black) is consistent with formation of diphenylphosphinyl radical. TA spectrum obtained by laser flash photolysis (310 nm pump) of a $1: 1 \mathrm{THF}: \mathrm{CH}_{3} \mathrm{CN}$ solution recorded at a $1 \mu$ s delay. (b) Thermal ellipsoid of 6 drawn at the 50\% probability level. The hydrogen atoms are omitted for clarity.

photolysis of either 2[TEA] (red spectrum, Fig. 3) or $\mathrm{PPh}_{3}$ (black spectrum, Fig. 3) leads to the observation of TA signals that are ascribed to diphenylphosphinyl radical. ${ }^{27}$ The lifetime of the diphenylphosphinyl radical derived from $\mathrm{PPh}_{3}$ with and without the presence of $2[\mathrm{TBA}]$ in solution is the same, consistent with no direct reaction between $\mathrm{Ni}(\mathrm{II})$ complex and diphenylphosphinyl radical (Fig. S19†). Substantial phosphine consumption is not required for $\mathrm{H}_{2}$ evolution because the diphenylphosphine generated during catalysis is a competent photoredox carrier. Nanosecond-resolved TA spectra, collected by laser flash photolysis of diphenylphosphine in THF, display the spectral features of diphenylphosphinyl radical (Fig. S20†), confirming that phosphine mediators can be catalytic..$^{27,40}$

That the photogenerated diphenylphosphinyl radical engages in HAA with THF to produce diphenylphosphine is confirmed by the isolation of complex $\mathbf{6}$, as a photo-byproduct of the photolysis of Ni complex 2[TEA]. Complex 6 features two C-bound tetrahydrofuranyl ligands on a phosphorus centre and could be derived from reaction of photogenerated diphenylphosphinyl radicals with furanyl radicals derived from HAA chemistry. Additionally we observed (GC-MS) octahydro-2,2'bifuran (homocoupled THF) as a photochemical byproduct. While HAA from THF by diphenylphosphinyl radicals is endothermic $\left(16 \mathrm{kcal} \mathrm{mol}^{-1}\right.$ uphill based on $\mathrm{P}-\mathrm{H}$ and $\mathrm{C}-\mathrm{H}$ bond 
dissociation energies), ${ }^{41}$ irreversible subsequent reactions, such as radical coupling to afford homocoupled THF sequester reactive radical intermediates. ${ }^{40}$

The rate for HAA from solvent by photogenerated diphenylphosphinyl is strongly correlated with solvent $\mathrm{C}-\mathrm{H}$ bond energies. ${ }^{27,42}$ We therefore anticipated that efficiency of the total catalytic process would be dictated by the turnover frequency of the photoredox mediator, which depends on the $\mathrm{C}-\mathrm{H}$ BDEs of $\mathrm{H}$-atom donor. The turnover frequency (TOF) of hydrogen generation from $\mathrm{HCl}$ with $\mathrm{Ni}$ complex 2 strongly depends on the solvent we employed, showing a positive correlation to the BDE of solvents: $0.34 \mathrm{~h}^{-1}$ TOF in THF, 0.05 $\mathrm{h}^{-1}$ TOF in $\mathrm{CH}_{3} \mathrm{CN}$, and $0.02 \mathrm{~h}^{-1}$ TOF in $\mathrm{C}_{6} \mathrm{H}_{6}$ (92, 96, and $112 \mathrm{kcal} \mathrm{mol}^{-1}$ of C-H BDEs respectively) (see Fig. S21 $\uparrow$ for details). ${ }^{4-45}$

To probe the potential fate of potential Ni(I) intermediates during catalysis, we examined the chemistry of isolated $\mathrm{Ni}(\mathrm{I})$ complexes. $\mathrm{Ni}(\mathrm{I})$ complex 3 can be isolated from the comproportionation reaction of $\mathrm{NiCl}_{2}(\mathrm{PPh})_{2}$ with $\mathrm{Ni}\left(\mathrm{PPh}_{3}\right)_{4}$. Based on the $E^{\circ}\left(\mathrm{Ni}^{\mathrm{II}} / \mathrm{Ni}^{\mathrm{I}}\right)$ and $E^{\circ}\left(\mathrm{Ni}^{\mathrm{I}} / \mathrm{Ni}^{0}\right)$ measured by cyclic voltammetry in THF (Fig. S22 $†$ ), comproportionation is thermodynamically favored. In contrast, in the presence of exogenous chloride ion, added as tetrabutylammonium chloride, disproportionation of $\mathrm{Ni}(\mathrm{I})$ complex 3 to $\mathrm{Ni}(\mathrm{II})$ complex $\mathbf{1}$ and $\mathrm{Ni}(0)$ complex $\mathbf{5}$ is observed, as determined by both ${ }^{31} \mathrm{P}$ NMR and electronic absorption spectroscopy (Fig. S8 and S14, $\dagger$ respectively). During $\mathrm{H}_{2}$ evolution photocatalysis, chloride is present in large excess $(68 \mathrm{mM})$ with respect to potential $\mathrm{Ni}(\mathrm{I})$ intermediates.

(a)
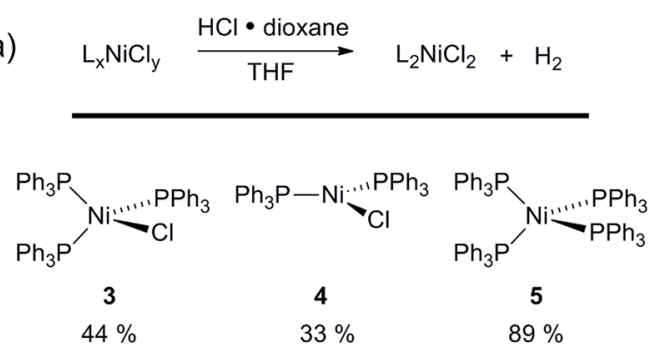

(b)

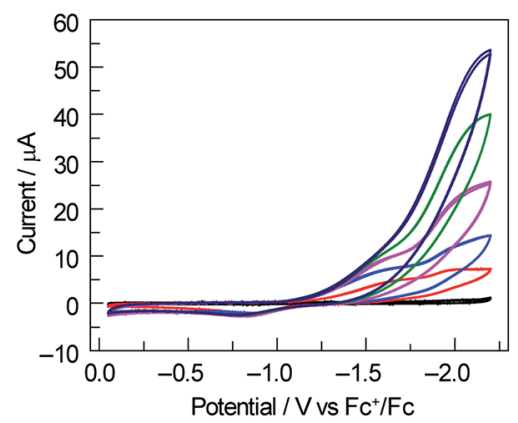

Fig. 4 (a) Protonation of $\mathrm{Ni}\left({ }_{1}\right)$ and $\mathrm{Ni}(0)$ complexes afforded $\mathrm{Ni}(॥)$ chloride as well as $\mathrm{H}_{2}$. (b) Electrochemical response of electrolyte background (-, black), $1 \mathrm{mM} \mathrm{Ni}$ complex 2[TEA] ( - , red) to addition of $\mathrm{HCl} 1.0$ equiv. ( - , blue), 5.0 equiv. ( - , pink), 9.0 equiv. ( - , green), 13.0 equiv. (-, dark blue) in $\mathrm{CH}_{3} \mathrm{CN}\left(0.1 \mathrm{M} \mathrm{NBu}_{4} \mathrm{PF}_{6}\right.$; scan rate, $100 \mathrm{mV} \mathrm{s}^{-1}$ ). Glassy carbon working electrode, $\mathrm{Ag} / \mathrm{AgNO}_{3}$ reference, and $\mathrm{Pt}$ wire counter electrode.

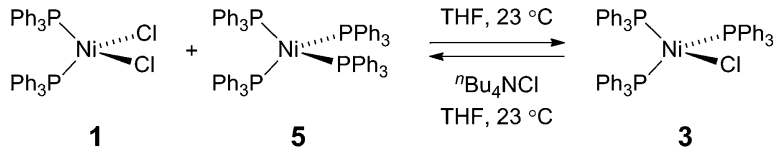

To assess whether the initially produced $\mathrm{Ni}(\mathrm{I})$ complex (3) or the $\mathrm{Ni}(0)$ complex (5) generated by disproportionation are active for $\mathrm{H}_{2}$ production, we examined the stoichiometric $\mathrm{H}_{2}$-evolution reaction chemistry of $\mathrm{Ni}(\mathrm{I})$ and $\mathrm{Ni}(0)$ complexes with $\mathrm{HCl}$. The results of these experiments are summarized in Fig. 4. Treatment of Ni complexes $\mathbf{3}, \mathbf{4}$, and $\mathbf{5}$ with 15 equiv. $\mathrm{HCl}$ in THF generates $\mathrm{H}_{2}$ in 44,33 , and $89 \%$ yields, respectively, along with $\mathrm{Ni}(\mathrm{II})$ complex 1, $\mathrm{NiCl}_{2}\left(\mathrm{PPh}_{3}\right)_{2}$. To gain insight into whether $\mathrm{H}_{2}$ evolution proceeds by protonation of $\mathrm{Ni}(\mathrm{I})$ or $\mathrm{Ni}(0)$, generated by disproportionation reactions, electrochemical $\mathrm{H}_{2}$ evolution was examined using $\mathrm{Ni}$ (II) trihalide complex 2[TEA]. As illustrated in Fig. 4, Ni complex 2[TEA] exhibits two electrochemically irreversible waves for the $\mathrm{Ni}^{\mathrm{II} / \mathrm{I}}$ and $\mathrm{Ni}^{\mathrm{i} / 0}$ couples at -1.62 and $-1.95 \mathrm{~V} v s . \mathrm{Fc}^{+} / \mathrm{Fc}$, respectively. In the presence of excess $\mathrm{HCl}$ $\left(\mathrm{p} K_{\mathrm{a}}=8.9 \text { in } \mathrm{CH}_{3} \mathrm{CN}\right)^{46}$ these two peaks exhibit catalytic cathodic waves. The dominant $\mathrm{CV}$ features of the $\mathrm{Ni}^{1 / 0}$ wave in the presence of excess $\mathrm{HCl}$ are consistent with $\mathrm{Ni}^{0}$ being involved in the $\mathrm{H}_{2}$ generating steps in our photocatalysis.

\section{Conclusions}

As is common for first-row transition metal complexes, nickel halide complexes typically exhibit very short excited state lifetimes. Direct photoactivation of $\mathrm{M}-\mathrm{X}$ bonds using the molecular excited states of these complexes has proven challenging owing to their short lifetimes. To circumvent the limitations imposed by short excited state lifetimes, we have developed a tandem photoredox/transition metal catalysis approach to $\mathrm{H}_{2}$ evolution in which the chromophore and the $\mathrm{H}_{2}$-evolution catalyst are localized on different molecules. Using diaryl phosphines as photoredox mediators, we have demonstrated that relatively non-basic phosphines are capable of acting as photoredox mediators under acidic conditions. Robust photocatalytic systems have been developed by combining phosphine photoredox mediators and $\mathrm{Ni}$ phosphine $\mathrm{H}_{2}$-evolution catalysts. Time-resolved spectroscopy has revealed that phosphines serve as photochemical $\mathrm{H}$-atom donors and activate the $\mathrm{M}-\mathrm{X}$ bonds of $\mathrm{Ni}(\mathrm{II})$ halide complexes via halogen-atom abstraction. The $\mathrm{H}_{2}$ evolution catalytic cycle is closed by sequential disproportionation of $\mathrm{Ni}(\mathrm{I})$ to afford $\mathrm{Ni}(0)$ and $\mathrm{Ni}(\mathrm{II})$ and protolytic $\mathrm{H}_{2}$ evolution from the $\mathrm{Ni}(0)$ intermediate. The described photoredox strategy is attractive in that independent optimization of photoredox mediator and $\mathrm{H}_{2}$-evolution catalyst provides multiple handles for system optimization.

\section{Acknowledgements}

We gratefully acknowledge Robert L. Halbach and D. Kwabena Bediako for helpful discussions, and the funding from NSF Grant CHE-1332783 and a Ruth L. Kirchenstein National Research Service award (F32GM103211) for D.C.P. 


\section{Notes and references}

\$ Crystallographic data for $2\left[\mathrm{ClPPh}_{3}\right]: \mathrm{C}_{36} \mathrm{H}_{30} \mathrm{Cl}_{4} \mathrm{P}_{2} \mathrm{Ni}, M=725.05$, orthorhombic, Pbca, $a=17.435(4), b=15.662(3), c=24.139(9), V=6591(2), Z=8, \mu=1.036$ $\mathrm{mm}^{-1}, T=100(2) \mathrm{K}, R_{1}=0.0527, \mathrm{w} R_{2}=0.0720$ (based on all reflections), GooF $=$ 1.030 , reflections measured $=57380$, unique reflections $=5858, R_{\text {int }}=0.0741$. Crystallographic data for 6: $\mathrm{C}_{40} \mathrm{H}_{48} \mathrm{Cl}_{4} \mathrm{O}_{4} \mathrm{P}_{2} \mathrm{Ni}, M=855.23$, monoclinic, $P 2{ }_{1} / n, a=$ 10.1261(8), $b=23.4579(18), c=17.8192(14), \beta=106.3550(12)^{\circ}, V=4061.4(5), Z=$ 4, $\mu=0.859 \mathrm{~mm}^{-1}, T=100(2) \mathrm{K}, R_{1}=0.0788, \mathrm{w} R_{2}=0.1328$ (based on all reflections), GooF $=1.005$, reflections measured $=44051$, unique reflections $=$ 7212, $R_{\text {int }}=0.0668$. Crystallographic data for $\mathrm{Cl}_{2} \mathrm{PPh}_{3}: \mathrm{C}_{18} \mathrm{H}_{15} \mathrm{Cl}_{2} \mathrm{P}, M=333.17$, monoclinic, $P 2_{1} / c, a=13.338(3), b=14.376(3), c=8.7454(17), \beta=102.53(3)^{\circ}, V=$ 1637.0(6), $Z=4, \mu=0.484 \mathrm{~mm}^{-1}, T=100(2) \mathrm{K}, R_{1}=0.0330, \mathrm{w} R_{2}=0.0710$ (based on all reflections), GooF $=1.060$, reflections measured $=18333$, unique reflections $=2874, R_{\text {int }}=0.0308$. Crystallographic data for $\left[\mathrm{ClPPh}_{3}\right] \mathrm{OTf}: \mathrm{C}_{19} \mathrm{H}_{15^{-}}$ $\mathrm{ClF}_{3} \mathrm{O}_{3} \mathrm{PS}, M=446.79$, monoclinic, $P 2_{1} / n, a=11.255(2), b=9.1501(18), c=$ 18.658(4), $\beta=93.04(3)^{\circ}, V=1918.7(7), Z=4, \mu=0.438 \mathrm{~mm}^{-1}, T=100(2) \mathrm{K}, R_{1}=$ $0.0425, \mathrm{w} R_{2}=0.0737$ (based on all reflections), $\mathrm{GooF}=1.031$, reflections measured $=18058$, unique reflections $=3392, R_{\mathrm{int}}=0.0362$.

1 A. J. Esswein and D. G. Nocera, Chem. Rev., 2007, 107, 4022. 2 D. G. Nocera, Inorg. Chem., 2009, 48, 10001.

3 A. F. Heyduk and D. G. Nocera, Science, 2001, 293, 1639.

4 A. J. Esswein, A. S. Veige and D. G. Nocera, J. Am. Chem. Soc., 2005, 127, 16641.

5 N. Elgrishi, T. S. Teets, M. B. Chambers and D. G. Nocera, Chem. Commun., 2012, 48, 9474.

6 T. R. Cook, Y. Surendranath and D. G. Nocera, J. Am. Chem. Soc., 2009, 131, 28.

7 T. S. Teets and D. G. Nocera, J. Am. Chem. Soc., 2009, 131, 7411.

8 T.-P. Lin and F. P. Gabbaï, J. Am. Chem. Soc., 2012, 134, 12230.

9 H. Yang and F. P. Gabbaï, J. Am. Chem. Soc., 2014, 136, 10866. 10 W. E. Van Zyl, J. M. López-de-Luzuriaga, J. P. Fackler Jr and R. J. Staples, Can. J. Chem., 2001, 79, 896.

11 J. P. Fackler Jr, Inorg. Chem., 2002, 41, 6959.

12 J. S. Ovens and D. B. Leznoff, Dalton Trans., 2011, 40, 4140.

13 T. A. Perera, M. Masjedi and P. R. Sharp, Inorg. Chem., 2014, 53, 7608.

14 A. R. Karikachery, H. B. Lee, M. Masjedi, A. Ross, M. A. Moody, X. Cai, M. Chui, C. D. Hoff and P. R. Sharp, Inorg. Chem., 2013, 52, 4113.

15 D. C. Powers, M. B. Chambers, T. S. Teets, N. Elgrishi, B. L. Anderson and D. G. Nocera, Chem. Sci., 2013, 4, 2880.

16 E. I. Carrera, T. M. McCormick, M. J. Kapp, A. J. Lough and D. S. Seferos, Inorg. Chem., 2013, 52, 13779.

17 For a recent counter-example, see: D. C. Powers, S. J. Hwang, S.-L. Zheng and D. G. Nocera, Inorg. Chem., 2014, 53, 9122.

18 C. H. Lee, D. A. Lutterman and D. G. Nocera, Dalton Trans., 2013, 42, 2355.

19 S. J. Tereniak, E. E. Marlier and C. C. Lu, Dalton Trans., 2012, 41, 7862.

20 E. A. Juban, A. L. Smeigh, J. E. Monat and J. K. McCusker, Coord. Chem. Rev., 2010, 254, 2677.
21 C. Creutz, M. Chou, T. L. Netzel, M. Okumura and N. Sutin, J. Am. Chem. Soc., 1980, 102, 1309.

22 C. H. Lee, T. R. Cook and D. G. Nocera, Inorg. Chem., 2011, 50, 714.

23 D. C. Powers, B. L. Anderson and D. G. Nocera, J. Am. Chem. Soc., 2013, 135, 18876.

24 K. Haav, J. Saame, A. Kütt and I. Leito, Eur. J. Org. Chem., 2012, 2167.

25 Y. Sakaguchi and H. Hayashi, J. Phys. Chem. A, 2004, 108, 3421.

26 D.-L. Versace, J. C. Bastida, C. Lorenzini, C. Cachet-Vivier, E. Renard, V. Langlois, J.-P. Malval, J.-P. Fouassier and J. Lalevée, Macromolecules, 2013, 46, 8808.

27 S. K. Wong, W. Sytnyk and J. K. S. Wan, Can. J. Chem., 1971, 49, 994.

28 A. B. Pangborn, M. A. Giardello, R. H. Grubbs, R. K. Rosen and F. J. Timmers, Organometallics, 1996, 15, 1518.

29 X.-F. Zhao and C. Zhang, Synthesis, 2007, 4, 551.

30 K. D. Schramm and J. A. Ibers, Inorg. Chem., 1980, 19, 2441.

31 T. Yano, M. Hoshino, M. Kuroboshi and H. Tanaka, Synlett, 2010, 5, 801.

32 M. C. Smith, S. C. Davies, D. L. Hughes and D. J. Evans, Acta Crystallogr., Sect. E: Struct. Rep. Online, 2001, 57, m509.

33 A. Schmidpeter and S. Lochschmidt, Inorg. Synth., 1990, 27, 253.

34 G. D. Stucky, J. B. Folkers and T. J. Kistenmacher, Acta Crystallogr., 1967, 23, 1064.

35 D. D. Ellis and A. L. Spek, Acta Crystallogr., Sect. C: Cryst. Struct. Commun., 2000, 56, 1067.

36 N. C. Norman, A. G. Orpen, M. J. Quayle and G. R. Whittell, Acta Crystallogr., Sect. C: Cryst. Struct. Commun., 2002, 58, $\mathrm{m} 160$.

37 G. Bontempelli, F. Magno, M. D. Nobili and G. Schiavon, J. Chem. Soc., Dalton Trans., 1980, 2288.

38 Y. Sakaguchi and H. Hayashi, Chem. Phys. Lett., 1995, 245, 591.

39 L. Maini, D. Braga, P. P. Mazzeo and B. Ventura, Dalton Trans., 2012, 41, 531.

40 M. L. Kaufman and C. L. Griffin, Tetrahedron Lett., 1965, 12, 769.

41 R. Waterman, Curr. Org. Chem., 2008, 12, 1322.

42 J. P. Roth, S. Lovell and J. M. Mayer, J. Am. Chem. Soc., 2000, $122,5486$.

43 L. J. J. Laarhoven, P. Mulder and D. D. M. Wayner, Acc. Chem. Res., 1999, 32, 342.

44 A. Cherkasov and M. Jonsson, J. Chem. Inf. Comput. Sci., 2000, 40, 1222.

45 W. van Scheppingen, E. Dorrestijn, I. Arends and P. Mulder, J. Phys. Chem. A, 1997, 101, 5404.

46 V. Fourmond, P.-A. Jacques, M. Fontecave and V. Artero, Inorg. Chem., 2010, 49, 10338. 